\title{
Authors' correction for "Effect of various soil cultivation methods on some microbial soil properties"
}

\section{Zsolt Sándor*}

Institute of Agrochemistry and Soil Science, University of Debrecen, Debrecen, Hungary

*Correspondence: Dr. Zsolt Sándor, email: zsandor@agr.unideb.hu, address: 138 Böszörményi Út, Debrecen, 4032

Hungary, Tel. number: +3652508444

Grant information: The author(s) declared that no grants were involved in supporting this work.

Copyright 2020 ( ) The Author(s). This is an Open Access article under the CC-BY 4.0 license published by Dama Research Center limited a private company limited by shares organized and existing under the laws of Hong Kong, with its head office located at Room 409, Beverley Commercial Centre, 87-105 Chatham Road South, Tsim Sha Tsui, Kowloon- Hong Kong and company number: 2875213.

How to cite: Sándor, Zs. "Authors' correction for "Effect of various soil cultivation methods on some microbial soil properties" DRC Sustainable Future 2020, 1(1): 21-22, DOI: 10.37281/DRCSF/1.1.31

We feel it our duty to communicate that soil respiration values were mentioned in the main text, but were not shown in table 2 in our previous study (Sándor et al., 2020). Please below find the corrected table including all microbial parameters. We apologize for the inconvenience.

Table 2. Some parameters of soil biological activity in a soil cultivation experiment, under irrigated and non-irrigated conditions (Látókép, Debrecen, April 1 and September 9, 2018.)

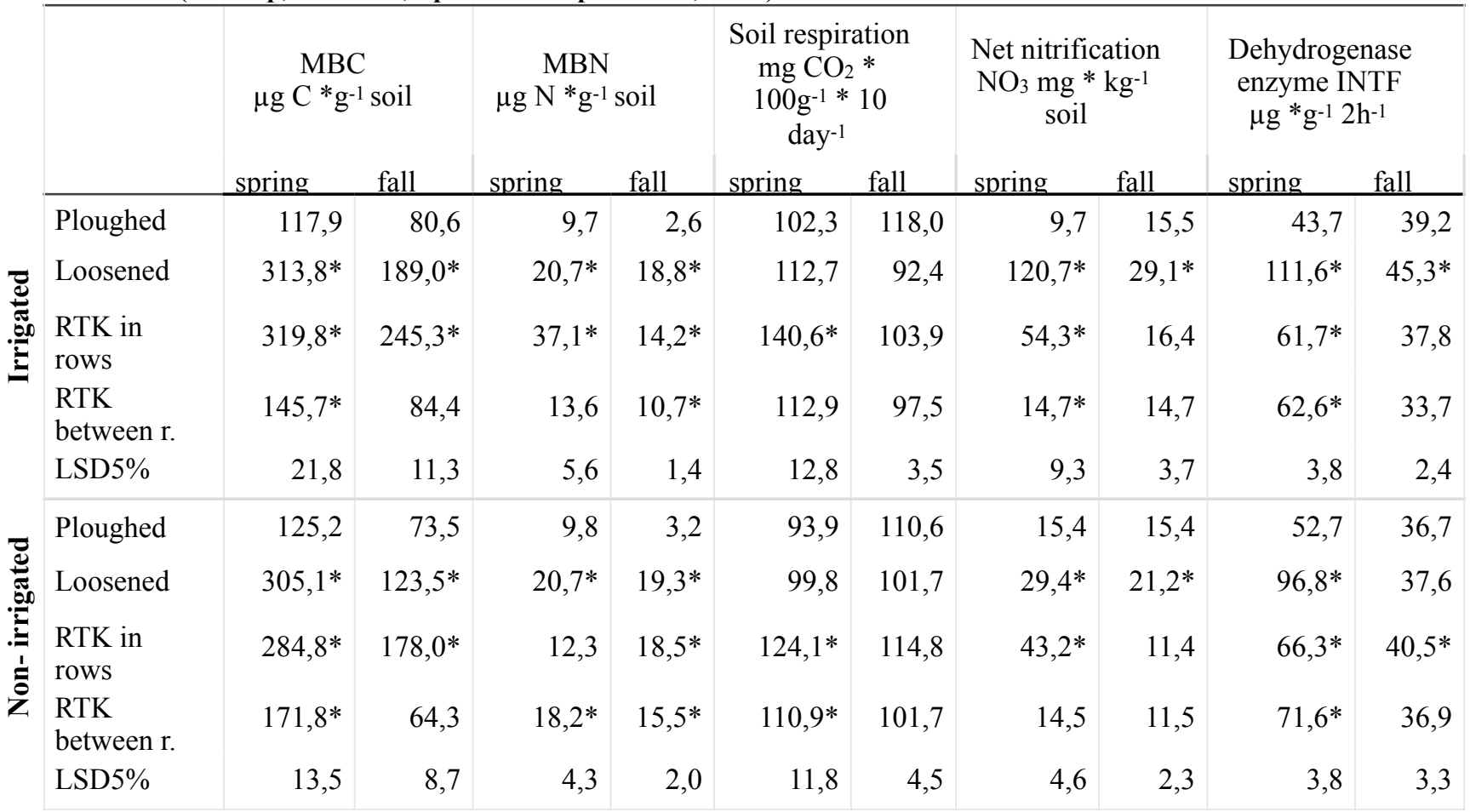




\section{References}

Sándor, Zs.; Tállai, M.; Kincses, I.; László, Z.; Kátai, J.; Vágó, I. (2020). "Effect of various soil cultivation methods on some microbial soil properties." DRC Sustainable Future 2020, 1(1):14-20. DOI: 10.37281/DRCSF/1.1.3 